\title{
Research on the application of Case-teaching method -take the curriculum Management for example
}

\author{
Liben Song ${ }^{1, a}$ \\ ${ }^{1}$ School of Ai En International, Dalian Jiao Tong University, Dalian 116021, China \\ abenjamin1717@163.com
}

Keywords: Case-teaching method,Management,necessity,teaching tactics

\begin{abstract}
Case-teaching method is one of the most important teaching methods.It is helpful for improving teachers professional qualification and good for creating a lively teaching atmosphere and cultivating students' ability to analyze and solve practical management problems,etc. According to the problems existed in the teaching process in Management. This paper applies case-teaching method in Management to indicate that the teaching method can improve the teaching quality greatly.
\end{abstract}

\section{Introduction}

The curriculum Management is the required course and core curriculum of the major of economy and Management discipline, it is a science of systematically researching the process of the rule, the basic, the principle and the general method in corporation management. The teaching effect of this course, Not only determines the students' learning interest and passion, and had a great influence on the later further study. For teachers should require students in the teaching process not only attach great importance to the basic concepts, theories and methods, but also the application in the practical problems. Therefore, it is necessary to strengthen the practice teaching process and cultivate the ability of solving problems in many aspects. Case-teaching method was Put forward and advocate by the Harvard Business School in 1920s,these cases are all from the real situation or Business Management event. In this way, it make advantageous to help the students take participate in the classroom activities.

\section{Necessity of case-teaching method in Management}

In the process of realization of the teaching purpose, teachers should cultivate students' ability of thinking, analyzing and solving problem, case-teaching method should be brought into the entire teaching process, to create scientifically and rigorously, pay attention to theory, and at the same time, pay attention to the practical teaching effect.

\subsection{Good for students to master and understand the theories}

Case-teaching method encourages students to think independently, and link the fragmentary cases with the Management theory easily, and make the abstract theories through the cases into the real situation, so strengthen students' perception of the Management theory.

\subsection{Good for creating a lively teaching atmosphere}

In the process of Case-teaching, the teacher is dominant and take the students as the main body, pay more attention to the teachers and students both sides involved in the active teaching methods. It requires teachers to fully grasp the teaching process and control the teaching result, and let the students to participate in the teaching process. Students could actively think the problems, put forward the solutions to solve the problems, and create a lively teaching atmosphere between teachers and students, so it is useful for achieving the goal of teaching.

2.3Good for cultivating students' ability to analyze and solve practical management problems

The learning process of Management, require students to put theoretical knowledge into practical skills, so as to solve practical problems in management. Case-teaching method can meet the 
requirements , it can put students in case scenarios through discussion and communication. Students need to use Management theories to analyze the phenomenon that the cases reflected, and put forward the opinions, communicate with the methods to solving the practical problems, in order to effectively cultivate the student's actual ability of analyzing and solving problem.

\section{Main problems in case-teaching}

\subsection{Teachers lack of management practice}

The teachers in universities are limited to the theoretical study, so they have not actual management work experience and teacher's own knowledge they have learned cannot be effectively apply to the management practice, it leads to the difficulties to creative a vivid teaching situation. Although some universities have strengthened the requirement of marketing practice, and to encourage to make the combination of teachers, enterprise and society, but because of the teachers' role positioning problem is very difficult to really in-depth marketing practice. Teachers' management practices tend to flow in the form.

\subsection{Teacher's leading role is not prominent, less communication with students}

In the implementation of case-teaching, the teacher cannot dominate the classroom teaching, sometimes can't effectively encourage the students' positive behavior. Some teachers even can't carry out the democracy principle in the process of discussion in the classroom and always strengthen their role as a teacher too much, less two-side communication between teachers and students, so lead to inhibit the maximum potential of students in case discussion.

\subsection{Students' participation in cooperation is not active enough}

Students have prejudice to case-teaching, they think that the cases which applied in the class are outdated, so have little impact on their later work. Many students are even influenced by social phenomenon, think that they can also do an excellent job even if without any Management knowledge. On other hand, the ways of teacher managing and controlling the case-teaching is not appropriate, so the atmosphere of classroom is depressing and cannot satisfy Students' higher psychological expectations.

\subsection{The case is not consistent with the teaching purpose}

When teaching the basic theories and methods, the case is simple which is isolated and irrelevant and it often cannot be consistent with the knowledge, so it is useless to help the students to understand and master the theory and students feel puzzled when they read and analyze the data in the cases .It is difficult to improve its application knowledge in management skills to solve practical problems.

\subsection{Less cases match to the textbook Management}

In case-teaching, carefully choosing the management case and the application is of vital importance. At the same time, the case must change with the change of the textbook. Teachers should update the cases all over the time. If teachers choose and adapt the cases all by themselves, it will cost a lot of time and energy. Therefore, in the teaching process, teachers probably may choose the case which is inaccurate, less realistic and atypical.

\subsection{Hard to finish the teaching task}

According to the curriculum plan, each course are fixed hours each semester. Teachers need to complete the teaching task within the corresponding time. If take the case-teaching method in the teaching process, students will take up a lot of discussion time, so at the end of the semester, the teaching content might not be finished. Thus, the number of course periods limit the case-teaching method In the actual teaching process, case-teaching method often change into list simple examples.

\section{Tactics to improve the implementation of the case-teaching in Management}

\subsection{Selecting carefully and strictly}

The case is the starting point of case-teaching and choose appropriate case is a prerequisite for successful implementation of case-teaching. 


\subsubsection{Pertinency}

Case Selecting should be based on the teaching goal and could achieve the target, the case and the teaching content should be an organic combination.

\subsubsection{Interesting}

The case selected should be lively and interesting, rich in colorful content and close to the student life. Considering more factors such as age, character and cognitive level, etc.

\subsubsection{Effectiveness}

With the fast development of Social and economy, the content and practice of enterprise management needs to be updated timely, teachers have to choose typical cases more closely related to the of era development in order to ignite students' learning passion.

\subsection{Give full play to teachers' leading role}

First of all, teachers should master the nature of the problem and the teaching goal reflected in the case, guide the discussion direction and encourage students to put forward different point of views. After finishing the case discussion to set aside a certain extra homework in order to deepen their own thinking. Secondly, teachers must be good at discovering and excavating the value of case resources, and understand the Management ideas and methods accurately. Finally, the teachers also should pay attention to the communication with the students' positively and patiently, observe real reaction of the students, in order to stimulate the exploring psychological.

\subsection{Use the modern teaching means, and continuously improve case-teaching method}

In modern information society, teachers should make full use of multimedia, network tools so as to stimulate students all-round brain nerve from multiple perspectives such as hearing, vision, aesthetics and display case content vividly, activate the students' thinking and improve teaching effect.

4.4Provide opportunities of the management practice, enhance practical management experience.

Through the establishment of university-enterprise cooperation pattern, create conditions for teachers' practical work experience. If the condition allows, the university can arrange teachers full-time engaging management work about $1 \sim 2$ years, or set up the social service department of Management consultancy, etc. It can facilitate teachers to practice enterprise management works, in order to effective auxiliary teaching.

\subsection{Improve students' performance assessment system}

Perfect students' performance assessment system could make students take part in the case discussion actively. To give scores according to the students' classroom performance in case analysis discussion and make the classroom performance become the main source of its formative assessment result, strengthen the student to take part in case discussion.

\subsection{Establish incentive mechanism}

Case-teaching is a complex task with a larger workload, so it is necessary to establish perfect teaching evaluation system, encourage and mobilize the teachers to actively participate in the training learning. The excellent case-teaching model could be observed and prompted. At the same time, the universities should formulate normative system and incentive measures to encourage teachers' taking part in the corporation practice positively, such as excellent case-teaching could be first published and attain the certificate of Qualification in priority.

\section{Summary}

Case-teaching is an important means of modern teaching, how to improve the teaching effect is worth studying seriously. Management is a applied science, In order to good use of case-teaching, teachers should innovate teaching model on the basis of the traditional teaching pattern. Not only teaching content should be more vivid, but also the teaching form be more abundant, so as to stimulate students to improve the ability of analyzing and solving problem. At the same time it also can improve the level of teachers' teaching ability. To promote the use of case-teaching actively, it is consistent with the requirement of Management teaching in universities. 


\section{References}

[1] Sharan,Merriam.Case study research in education-A qualitative approach,1988 by Jossey-Bass inc Limited,1997,15(3):167-212

[2] GuorongYao, LinLu.Research on Class teaching reform of Management [J].Beijing,Statistical education, 2007(3):35-36

[3] Editorial committee of the ministry of education of the People's Republic of China. Abstract of Quality education concept learning [M].Beijing,San Lian press, 2001

[4]Yuan Yuan,Jian Chen.Study on the teaching method of management[J].Academic Journal of Southwest nationalities university (social science ),2003(10):36-38

[5] Talhelm, T., X. Zhang, S. Oishi, C. Shimin, D.Duan, X. Lan, and S. Kitayama. Large-Scale Psychological Differences within China Explained by Rice versus WheatAgriculture[J].Science, 2014, 344 (6184):603-608. 